Dr ANDREJ BORISOVIČ EDEMSKI, viši naučni saradnik

Institut slavistike Ruske akademije nauka

Moskva, Ruska Federacija

and-edem@yandex.com

MA MOMIR N. NINKOVIĆ, doktorand

Filozofski fakultet, Univerzitet u Beogradu

Beograd, Republika Srbija

momirninkovic22@gmail.com

originalan naučni rad

UDK: 327:316.7(497.1:47)"195"

primljeno: 24. april 2019.

821.163.41:929 Ћосић Д.

prihvaćeno: 22. maj 2019.

821(47):061.2"1954"

https://doi.org/10.29362/ist20veka.2019.2.ede.195-216

\title{
„MISIJA DOBRE VOLJE“. DOBRICA ĆOSIĆ NA DRUGOM SVESAVEZNOM KONGRESU SOVJETSKIH KNJIŽEVNIKA (15-26. DECEMBAR 1954)
}

APSTRAKT: U članku je razmatrano učešće jugoslovenskih delegata, posebno Dobrice Ćosića, na Drugom svesaveznom kongresu sovjetskih književnika. Rad predstavlja prilog izučavanju procesa normalizacije jugoslovenskosovjetskih odnosa posle sukoba 1948. godine. Poseban akcenat stavljen je na obnavljanje kulturnih i književnih veza dve države i na ulogu koju je u tome $i$ mao D. Ćosić (može se posmatrati i kao prilog biografiji D. Ćosića). Rad je zasnovan na neobjavljenim dokumentima arhiva u Republici Srbiji i Ruskoj Federaciji, dnevničkim zapisima D. Ćosića, objavljenim zbirkama dokumenata, periodici i stručnoj istoriografskoj literaturi.

KLJUČNE REČI: Jugoslavija, Sovjetski Savez, Dobrica Ćosić, Marin Franičević, normalizacija, Drugi kongres sovjetskih pisaca, 1954, Leonid Leonov, Ida Markovna Radvoljina

Učešće jugoslovenskih književnika - Dobrice Ćosića i Marina Franičevića $^{1}$ - na Drugom svesaveznom kongresu sovjetskih književnika u decembru 1954. i rezultati njihovog boravka u SSSR-u nisu detaljnije razmatrani u srpskoj istoriografiji, već su samo usputno pominjani u nekoliko monografija. ${ }^{2} \mathrm{U}$ stra-

\footnotetext{
${ }^{1}$ Marin Franičević (1911-1990), hrvatski pesnik, istoričar književnosti i kritičar. Opširnije, sa dodatnom literaturom: Zoran Kravar, „Franičević, Marin“, Hrvatski biografski leksikon, 4, EGm (Zagreb: Leksikografski zavod „Miroslav Krleža“, 1998) 372-374.

2 Предраг Ј. Марковић, Београд између Истока и Запада 1948-1965 (Београд: Службени лист СРЈ, 1996), 404-405; Миомир Гаталовић, Дарована слобода. Партија и култура у Србији 1952-1958 (Београд: ИСИ, 2010), 166; Горан Милорадовић, Лепота под надзором.
} 
noj istoriografiji ovim pitanjem se nedavno bavio književni istoričar Jevgenij Aleksandrovič Dobrenko koji je temu posmatrao pre svega u kontekstu nastupa književnika iz Istočne Evrope na Kongresu. ${ }^{3}$ Zbog velikog značaja perioda tokom koga je Kongres održan za dalju normalizaciju odnosa dve države, ova tema je važna ne samo za razumevanje procesa obnove kontakata između jugoslovenskih i sovjetskih pisaca i kulturnih veza dve države, već i za potpunije razumevanje sveobuhvatne normalizacije odnosa Beograda i Moskve. I D. Ćosić i M. Franičević su ostavili svedočanstva o svom boravku u SSSR-u. ${ }^{4}$ Međutim, obim izvora koji se odnose na Ćosića i - pre svega - činjenica da sovjetski dokumenti o njemu na dobar način upotpunjavaju saznanja iz jugoslovenskih izvora, uputili su nas na to da kroz njegovu delatnost pokušamo da sagledamo ovu važnu temu. ${ }^{5}$ Iako su na jugoslovenskoj strani pažljivo praćeni, atmosfera

Совјетски културни утииаји у Југославији 1945-1955 (Београд: ИСИ, 2012), 216; Слободан Селинић, Книжевна дипломатија. Међународна сарадња југословенских писача од средине педесетих до краја седамдесетих година 20. века (Београд: ИНИС, 2019), 49.

${ }^{3}$ Deo članka o učešću jugoslovenskih književnika na Kongresu je zasnovan na dokumentima Ruskog državnog arhiva književnosti i umetnosti i dobro je uklopljen u širu temu koju je Dobrenko obrađivao. Međutim, ako ga posmatramo izdvojeno, sa stanovišta jugoslovensko-sovjetskih odnosa, kao primedbe se mogu navesti nedostatak jugoslovenskih izvora, nepoznavanje književnih prilika u FNRJ i nedovoljno poznavanje jugoslovensko-sovjetskih odnosa. Na primer, previđajući čitav niz stvari iz druge polovine 1954. godine, on prenaglašeno smatra da je ,upravo sa pozivom jugoslovenskim piscima Dobrici Ćosiću i Marinu Franičeviću na Drugi kongres pisaca u Moskvu počelo postepeno otopljavanje odnosa sa Jugoslavijom“ (školski primer ,pogleda kroz tunel“). Takođe, podaci iz izvora su prenošeni nepažljivo, sa greškama. Autor umesto „Glembajevi“ piše „Šlembajevi“, umesto „Vjekoslava“ (Kaleba) piše „Visoslav“, što govori i o nepoznavanju književnih prilika u FNRJ. U članku ima i nekoliko činjeničnih grešaka, poput onih da je D. Ćosić radio u agitpropu CK KPJ (treba: CK KPS) ili da je njegov roman „Daleko je sunce“ objavljen 1952, a štampan je 1951. godine. Е. А. Добренко, „Восточноевропейские литературы на Втором съезде писателей и проект литературного Рах Sovietica: начало конца“, у: Второй Всесоюзный съезд советских писателей. Идеология исторического перехода и трансформачия советской литературы. 1954: коллективная монография, отв. ред. В. Ю. Вьюгин (Санкт-Петербург: Алетейя, 2018), 155-164.

4 Добрица Ћосић, Пишчеви записи (1951-1968), друго издање (Београд: Филип Вишњић, 2001), 67-97; Мирко Милорадовић, „Добрица ћосић о књижевној Москви, „Коренима“ и себи“, Студент, бр. 7, 23. 3. 1955, 5; D. Ćosić, „Susret u Moskvi“, Delo, br. 1, (mart 1955), 8-18; „Kongres sovjetskih pisaca u očima jugoslavenskog delegata M. Franičevića. Odgovori na pitanja naše redakcije“, Vjesnik u srijedu, 12. 1. 1955, 6; „Марин Франичевић о совјетској књижевности“, Борба, 12. 1. 1955, 5; Marin Franičević, „Drugo putovanje u SSSR“, Vjesnik, 22. 1. 1955, 5; Isti, „Oko kongresa“, Isto, 23. 1. 1955, 6; Isti, „Kontradikcije i nesporazumi“, Isto, 24. 1. 1955, 5; Isti, „Gosti na govornici. Odnos prema Jugoslaviji“, Isto, 25. 1. 1955, 5.

${ }^{5}$ Iako se M. Franičević formalno nalazio na čelu delegacije, Sovjeti su njemu poklanjali značajno manju pažnju. Izgleda da su u presudnoj meri na to uticali tipovi ličnosti dva književnika. Naspram zatvorenog, opreznog i suzdržanog hrvatskog pesnika, D. Ćosić se odlikovao neposrednošću i pokazivao veliku zainteresovanost da sazna nove stvari. Među sovjetskim dokumentima se po značaju izdvaja izveštaj Ide Litvakove koja je bila prevodilac i pratilac jugoslovenskim književnicima tokom Kongresa - Российский государственный архив новейшей истории (РГАНИ), Ф. 5 (Аппарат ЦК КПСС), Оп. 28 (Отдел ЦК КПСС по связам с иностранными компартиями, 1953-1957), Д. 342, Л. 19-39, О Югославских писателях - гостях съезда советских писателей Добрице Чосиче и Марине Франичевиче. Докладная записка. Judif Markovna Litvakova, pseudonim Ida Markovna Radvoljina (1911-2001), pisac, književni kriti- 
pre, tokom i posle Kongresa i teme koje su diskutovane, teoretska pitanja (poput onih o ,pozitivnom heroju“ ili ,teoriji beskonfliktnosti“) i istupanja pojedinih književnika, nemaju važnost za odnose FNRJ i SSSR-a, kao što je to slučaj sa pokazivanjem ,dobre volje“ i razmatranjem konkretnih pitanja u vezi sa obnavljanjem kulturnih veza, kojima ćemo posvetiti pažnju u radu. ${ }^{6}$

Književne i uopšte kulturne veze socijalističke Jugoslavije i Sovjetskog Saveza bile su tesno povezane i uslovljene njihovim političkim odnosima. ${ }^{7} \mathrm{Zbog}$ toga učešće jugoslovenskih književnika na Kongresu treba posmatrati kao jedan od događaja „u sklopu priprema za 'pomirenje' Hruščova i Tita“. ${ }^{8}$ Početkom 1955. na jugoslovenskoj strani su smatrali da će saradnja u oblasti kulture i u narednom periodu zavisiti „u prvom redu od stepena razvitka ostalih međusobnih odnosa“, a $\mathrm{u}$ toku godine su navodili da kulturna saradnja predstavlja ,sastavni deo normalizacije odnosa“, ali su i uočavali da „Rusi nastoje da ovoj saradnji pridaju karakter političkih manifestacija i da [je] dobrim delom iskoriste u političko propagandne svrhe“". ${ }^{9}$ Kako su politički odnosi FNRJ i SSSR-a u periodu na koji se odnosi ovaj $\mathrm{rad}-\mathrm{i}$ uopšte $\mathrm{u}$ čitavom razdoblju normalizacije odnosa $-\mathrm{u}$ istoriografiji dobro pokriveni, da bismo temu članka stavili u odgovarajući kontekst usredsredićemo se u uvodnom delu na proces obnove kulturnih veza $\mathrm{i}$ kontakata. ${ }^{10}$

Prva ozbiljnija nastojanja da se obnove pokidane veze u oblasti kulture preduzeta su krajem 1953. i početkom 1954. godine kada je predstavnik Svesaveznog društva za kulturne veze sa inostranstvom (VOKS) u Beogradu, A.

čar. Od 1945. do 1950. živela u Jugoslaviji (njen suprug Dragan Ozren je uhapšen po izbijanju sukoba 1948; stradao je 1951. godine). Po povratku u SSSR u Savezu književnika je radila kao konsultant za jugoslovensku književnost. U Srbiji je prevedeno i objavljeno njeno memoarsko delo: Ида Марковна Радвољина, Дугачко писмо које није стигло до примаоия (Сремски Карловци-Нови Сад: Издавачка књижарница Зорана Стојановића, 2011).

${ }^{6}$ Opširnije o percepciji Kongresa od strane jugoslovenskih diplomata iz Moskve: Diplomatski arhiv Ministarstva spoljnih poslova Republike Srbije (DA MSP), Politička arhiva (PA), 1954, fascikla 86, dosije 13, 415008, O pripremama za II Svesavezni kongres književnika SSSR, Mladen Božić, 1. 11. 1954; Isto, 1955, f. 62, dos. 19, 42210, O II kongresu sovjetskih pisaca, B. Osolnik; Isto, 43982, Neki problemi sovjetske literature posle II kongresa pisaca, D. Rožman, 18. 3. 1955. Opširnije o samom Kongresu: Второй Всесоюзный съезд советских писателей. Идеология исторического перехода и трансформачия советской литературы...

${ }^{7}$ Мирослав Јовановић, Срби и Руси 12-21. век (историја односа) (Београд: Народна библиотека Србије, 2012), 25, 203; С. Селинић, н. д., 8, 191, 385.

${ }^{8}$ Г. Милорадовић, н. д., 216.

${ }^{9}$ DA MSP, PA, 1955, f. 64, dos. 8, 18864, Mogućnosti i uslovi dalje saradnje; Isto, f. 65, dos. 6 , 41046, Bogdan Osolnik - Državnom sekretarijatu za inostrane poslove FNRJ, 20. 1.1955.

${ }^{10} \mathrm{O}$ normalizaciji jugoslovensko-sovjetskih odnosa opširnije: Ljubodrag Dimić, ,Jugoslovenskosovjetski odnosi u 1954. godini (hronologija događaja)“, u: Balkan posle Drugog svetskog rata. Zbornik radova sa naučnog skupa, odg. ur. Petar Kačavenda (Beograd: ISI, 1996), 155-165; Isti, „Jugoslovensko-sovjetski odnosi 1953-1956. Zbliženje, pomirenje, razočarenje“, u: Jugoslovensko-sovjetski sukob 1948. godine. Zbornik radova sa naučnog skupa, odg. ur. P. Kačavenda (Beograd: ISI, 1999), 279-293; Radoica Luburić, prir., Pomirenje Jugoslavije i SSSR-a 1953-1955. Tematska zbirka dokumenata (Podgorica: Istorijski institut CG, 1999); Jan Pelikán, Jugoslávie a východní blok 1953-1958 (Praha: Univerziteta Karlova v Praze, 2001), 17-208; Андрей Борисович Едемский, От конфликта к нормализаиии. Советско-югославские отнотения в 1953-1956 годах (Москва: Наука, 2008), 55-599. 
Grecki nastojao da aktivira delatnost Doma sovjetske kulture (DSK). Na projekcije novih sovjetskih filmova koji su počeli da se prikazuju u DSK, on je pozivao i jugoslovenske kulturne radnike - ,pozorišne i filmske glumce, operske pevače, balerine, pisce, režisere, novinare i sl.“ Uočavajući pojačanu aktivnost DSK (i sovjetskih diplomata uopšte), Državni sekretarijat za inostrane poslove (DSIP) poslao je sredinom januara 1954. instrukciju jugoslovenskim diplomatama u Moskvi da i oni treba da ,pojačaju sličnu aktivnost“", da ,uspostave kontakte sa širim krugom ljudi“", između ostalog i sa direktorima ustanova kulture i da ispitaju mogućnost „neke razmene naučnih publikacija i slično“. Izveštavajući 15. februara 1954. rukovodstvo VOKS-a o rezultatima svojih kontakata sa predstavnicima različitih ustanova kulture, umetničkih saveza i sa pojedinim kulturnim poslenicima Jugoslavije, Grecki se posebno zadržao na razgovoru koji je vodio sa savetnikom Komisije za kulturne veze sa inostranstvom Nikolajevićem, koji je saopštio da „među kulturnim radnicima Jugoslavije bezuslovno postoji veliki interes za sovjetsku kulturu“. Kao svoje lično mišljenje Nikolajević je naveo da „kulturne veze između Jugoslavije i SSSR-a treba razvijati“", dodajući da inicijativa treba da bude na sovjetskoj strani, ,jer je SSSR svojevremeno prekinuo te veze“. Istom prilikom, povodom razgovora sa generalnim sekretarom Saveza književnika Jugoslavije (SKnjJ) Aleksandrom Vučom, Grecki je javljao da je on ,izrazio žaljenje što su silom političkih odnosa između Jugoslavije i SSSR-a, pisci Jugoslavije lišeni mogućnosti da prate sovjetsku književnost, i da on lično gotovo ništa ne zna šta se kod nas dešava u oblasti književnosti“. Vučo je nazvao „nenormalnim“ stanjem „kada su dve slovenske književnosti izolovane jedna od druge“, i govoreći o kulturnim kontaktima dve zemlje naglasio da ,stanje sada treba da se izmeni, ali sve to treba da ide postepeno“. U martu 1954. su i u DSIP-u i u jugoslovenskoj ambasadi u Moskvi bili saglasni da će „Rusi ići na širu ekonomsku, kulturnu [istakli autori], naučnu i sportsku saradnju sa nama“ i da će njihove inicijative u tom pravcu biti „u skladu sa njihovom današnjom spoljnom politikom i neposrednim političkim ciljevima prema Jugoslaviji“‘. Krajem marta sovjetski ambasador Vasilij Aleksejevič Valjkov je predlagao „razmenu filmova, umetnika i slično“ i govoreći o „potrebi uspostavljanja kulturnih veza" insistirao na jugoslovenskoj inicijativi. ${ }^{11}$

U toku razgovora u kojima su obe strane izražavale želju za razvojem kulturnih veza, sredinom maja 1954. postignut je prvi načelni dogovor i to o pitanju „najvažnije umetnosti“ - filma; ambasador Valjkov se saglasio sa predlogom predsednika Komisije za kulturne veze sa inostranstvom Marka Ristića „da se dogovorimo o razmeni filmova, tako da se i jugoslovenski prikazuju u

${ }^{11}$ Југословенско-совјетски односи 1945-1956. Зборник докумената, прир. Љ. Димић и др. (Београд: Министарство спољних послова Републике Србије, 2010), док. 283, 286, стр. 643-644, 649, 650; РГАНИ, Ф. 5, Оп. 28, Д. 239, Л. 8-9, Уполномоченный ВОКС в Югославии А. Грецкий - Председателю Правления ВОКС Денисову А. И, 15. 2. 1954; DA MSP, PA, 1954, f. 86, dos. 21, 43967, Vidić - Sekretarijatu za inostrane poslove, 30. 3. 1954; Isto, 1955 , f. 63 , dos. 5,18872 , Kulturna i naučna saradnja sa istočno-evropskim državama. Jugoslavija-SSSR. 
SSSR-u“. ${ }^{12}$ Od razmene mišljenja i načelne saglasnosti do potpisivanja ugovora o razmeni filmova između beogradske Avale i Soveksportfilma krajem 1955. predstojao je dug put i rešavanje složenih pitanja tokom dvomesečnih direktnih pregovora. ${ }^{13}$ Međutim, od sredine godine - posle donošenja tajne odluke „o odnosima prema Jugoslaviji“ “ Prezidijuma Centralnog komiteta Komunističke partije Sovjetskog Saveza od 31. maja 1954 - postepeno je ubrzavano kretanje ka obnovi kulturnih i drugih veza između dve države, a u junu je otpočela i poznata tajna prepiska rukovodstva dve partije. ${ }^{14}$

Od sredine septembra Sovjeti su dodatno pojačali svoju aktivnost po ovim pitanjima, insistirali ,na ubrzanju kulturnih odnosa, razmeni filmova, pozorišta, akademika“, isticali ,potrebu saradnje na kulturnom [...] i drugim poljima“, navodili da „treba odlučnije ići dalje“", pominjali da bi trebalo ,preći sa reči na dela, dogovorivši se, na primer, o razmeni literature, filmova i t. d.“ Jugosloveni su se slagali da na tim pitanjima treba raditi, ali postepeno, da se ,postepeno ide na bolje“, i na sovjetsko požurivanje ukazivali „da je za tako što potrebna pogodna atmosfera, koja [...] sa njihove [sovjetske - prim. autora] strane nije još pripremljena“. Govoreći o ,nepostojanju [...] potrebne atmosfere“ u SSSR-u,

12 Југословенско-совјетски односи 1945-1956, док. 288, стр. 657; DA MSP, 1954, f. 87, dos. 11, 46232, Zabeleška o razgovorima kod sovjetskog ambasadora g. Valjkova, Bebler, 12. 5. 1954.

13 Opširnije: РГАНИ, Ф. 3 (Политбюро ЦК КПСС), ОП. 10 (Протоколы заседаний Президиума ЦК КПСС), Д. 119, Л. 17, Протокол № 99 заседания Президиума ЦК КПСС от 20 декабря 1954 г. (постановления за 15-20 декабря 1954 г.); Исто, Ф. 5, Оп. 28, Д. 239, Л. 54, Из дневника Валькова В. А, 21 сентября 1954; „Постигнут споразум о купопродаји совјетских и југословенских филмова“, Борба, 28. 12. 1954, 6; „Потписан уговор о размени наших и совјетских филмова“, НИН, бр. 209, 1. 1. 1955, 28; Arhiv Jugoslavije (AJ), fond 837, Kabinet predsednika Republike (KPR), I-5-b/99-1, Zabeleška o razgovoru opunomoćenog ministra Dragoja Đurića sa Starcevom, savetnikom sovjetske ambasade, na dan 20. 11. 1954; DA MSP, PA, 1954, f. 87, dos. 11, 415325, Zabeleška o razgovoru državnog podsekretara Aleša Beblera sa sovjetskim ambasadorom g. Valjkovim na večeri kod druga Beblera, 10. 12. 1954; Isto, f. 88, dos. 10, 416084, Zabeleška povodom razgovora pretstavnika „Sov. eksport filma“ Zimina i pretstavnika Jugoslovenskih filmskih preduzeća o razmeni i kupovini filmova; Isto, Cicmil - Ambasadi FNRJ - Moskva, 30. 12. 1954.

${ }^{14}$ U odluci CK KPSS od 31. maja 1954. navedeno je da bez obzira na to što su sa sovjetske strane preduzeti određeni koraci prema normalizaciji diplomatskih odnosa sa Jugoslavijom (koji su bili u okviru normi i odnosa „sa kapitalističkim državama“), treba istaći: „U oblasti ekonomske saradnje, trgovine, sportskih i kulturnih veza još su se sačuvala ograničenja, kakvih nema za druge buržoaske države, koje imaju diplomatske odnose sa nama“. Istaknuto je da CK KPSS smatra da „postoje izvesni uslovi za popravljanje odnosa između SSSR-a i Jugoslavije“ i da bi „sa tačke gledišta interesa Sovjetskog Saveza“ trebalo iskoristiti tu mogućnost. U vezi sa tim CK KPSS je smatrao da je svrsishodno „,preduzeti nove korake za popravljanje diplomatskih, ekonomskih i kulturnih međusobnih odnosa sa Jugoslavijom, imajući u vidu sprečavanje konačnog prelaza Jugoslavije u lager imperijalizma, širenje mogućnosti za jačanje našeg uticaja na jugoslovenski narod“. Југословенско-совјетски односи 1945-1956, док. 289, стр. 658; Встречи и переговоры на высшем уровне руководителей СССР и Югославии в 1946-1980 г2. Том первый 1946-1964, глав. ред. М. Милошевич, В. П. Тарасов, Н. Г. Томилина, Москва: Международный фонд „Демократия“, 2014, 580, 581-582. Detaljnije o diskusiji u sovjetskom rukovodstvu povodom donošenja pomenute odluke, početku i odvijanju tajne prepiske, kao i o odnosima dve države do kraja 1954. godine: А. Б. Едемский, н. д., 226-351; Lj. Dimić, „Jugoslovensko-sovjetski odnosi u 1954. godini...“, 157-164. 
Jugosloveni su s jedne strane navodili kako im ,pada u oči ignorisanje Jugoslavije u njihovoj javnosti, da se u štampi gotovo ništa ne beleži o nama, da na njihovom muzičkom i pozorišnom repertoaru nema naših dela, da tako isto stoji stvar u njihovoj izdavačkoj delatnosti itd“; a s druge su pominjali ,da je za razliku od njih kod nas situacija sasvim drukčija, da se na repertoarima u svim oblastima našeg kulturnog života nalaze stalno i dela ruskih klasičnih i savremenih autora“". Sovjeti su pokušavali da ublaže takve ocene, navodeći kako oni „,poštuju kulturna, umetnička i druga dostignuća svih naroda pa i naša, da je na primer Nušićeva 'Gospođa ministarka' bila i da će opet biti na repertoaru“, pominjali da se u jugoslovenskoj štampi ,naročito u unutrašnjosti mogu još uvek naći stvari o SS [Sovjetskom Savezu] koje su neprikladne za dostignuti nivo naših odnosa", kao i da se u Jugoslaviji više piše o SSSR, ali da se kod njih piše pozitivnije. ${ }^{15}$ Postepeno, približavanjem 1954. godine kraju, Sovjeti su sve više konkretizovali svoje predloge za saradnju u oblasti kulture. Na osnovu instrukcija CK KPSS-a „o merama za obnavljanje kulturnih veza između SSSR-a i Jugoslavije“, ministar kulture SSSR-a G. F. Aleksandrov je 28. oktobra 1954. jugoslovenskom ambasadoru u Moskvi Dobrivoju Vidiću izneo niz konkretnih predloga za obnovu kulturnih veza: „započinjanje preštampavanja ranijih i izdavanja novih knjiga sovjetskih pisaca u Jugoslaviji“", ,prevođenje i štampanje jugoslovenske marksističke, naučne i umetničke literature na ruskom", razmena „umetničkih i drugih izložbi“", kupoprodaja filmova, uzajamne posete umetnika, razmena naučne literature. ${ }^{16}$

Početkom oktobra 1954. jugoslovenskoj strani je predočavano kako je „CK [KPSS] izvršio ozbiljnu samokritiku u pitanju odnosa prema FNRJ“, da „CK KPSS u istinu želi popraviti stvari“ $\mathrm{i}$ da treba „da obnovimo staro prijateljstvo, da prošlost damo đavolu, da od toga nikom nije bilo koristi““. ${ }^{17} \mathrm{U}$ sklopu takvih, širih sovjetskih nastojanja za obnavljanjem odnosa u kulturi i, pre svega, u težnji za sveobuhvatnom normalizacijom odnosa između dve države, Savez sovjetskih književnika (SSK) obavestio je 18. oktobra 1954. SKnjJ o održavanju Svesaveznog kongresa sovjetskih književnika i - ,računajući da će takav susret na Kongresu biti uzajamno koristan“ - pozvao dva jugoslovenska pisca da prisustvuju. Zahvaljujući na pozivu, generalni sekretar SKnjJ A. Vučo je 6. novembra 1954. obavestio sekretara Uprave SSK Borisa Poljevoja da će kao jugo-

\footnotetext{
${ }^{15}$ AJ, KPR, I-5-b/99-1, Zabeleška o razgovorima državnog podsekretara Veljka Mićunovića i ambasadora Vidića kod sovjetskog ambasadora g. Valjkova na večeri 13. 9. 1954; РГАНИ, Ф. 5, Оп. 28 , Д. 239, Л. 64-65, Из дневника Грязнова Ф. Н, Запись беседы с зам. Заведующего Политическим отделом Госсекретариата по иностранным делам ФНРЮ Д. Джуричем, 21. 9. 1954; Југословенско-совјетски односи 1945-1956, док. 297, стр. 675; DA MSP, PA, 1954, f. 87, dos. 9, 415268, Vidić - Sekretarijatu za inostrane poslove, 19. 12. 1954; Isto, dos. 11, 413338, Zabeleška o razgovoru op. ministra Dragoja Đurića sa Grjaznovom, savetnikom sovjetske ambasade, na dan 21. 9. 1954; Isto, 413710, Zabeleška o razgovoru op. ministra Dragoja Đurića sa Starcevim, savetnikom sovjetske Ambasade, na dan 19. 10. 1954.

16 Југословенско-совјетски односи 1945-1956, док. 298, 304, стр. 678-679, 690-691; AJ, KPR, I-5-b/99-1, Zabeleška o razgovoru ambasadora FNRJ u Moskvi D. Vidića s Aleksandrovim, ministrom kulture SSSR na dan 28. oktobra 1954.

${ }^{17}$ Југословенско-совјетски односи 1945-1956, док. 301, стр. 684-685.
} 
slovenski delegati Kongresu prisustvovati M. Franičević i D. Ćosić. Istog dana ovo obaveštenje je objavljeno u partijskom glasilu Borbi! ${ }^{18}$

Pregledani dokumenti nam ne daju objašnjenje zbog čega su Ćosić i Franičević odabrani kao delegati. Ipak, može sa navesti nekoliko činilaca koji su mogli da imaju uticaja pri izboru. Prema jednoj pretpostavci, njihovo određivanje je imalo određenu vezu sa podelom jugoslovenskih pisaca na moderniste $\mathrm{i}$ realiste i njihovim sukobom. Kako se ,u nekim velikim protokolarnim dešavanjima, vodilo [...] računa da budu prisutni i realisti i modernisti“, za prvi kontakt jugoslovenskih i sovjetskih pisaca posle 1948. godine izabran je ,jedan pisac iz tabora realista“ (Franičević) i, jedan iz tabora modernista" (Ćosić). ${ }^{19} \mathrm{~S}$ obzirom na to da su Ćosić i Franičević dolazili iz dve najznačajnije jugoslovenske republike, navodimo ovde kao pretpostavku da je i ta činjenica mogla imati ulogu pri izboru. Poznato je da se pri određivanju književnika za put u inostranstvo prvenstveno vodilo računa ,o dejstvu (stručnom i političkom) koje se od svakog delegata očekuje u određenoj inostranoj zemlji““. ${ }^{20}$ Sigurno je da je u izuzetno važnom trenutku za normalizaciju odnosa dve države politička komponenta imala ogromnu važnost u određivanju kandidata i da je politika bila ta koja je imala ključnu ulogu u njihovom izboru. Ulogu političkog faktora (CK) posredno potvrđuju i Ćosićeve reči izgovorene usput pri šaljivom pomenu razlike $u$ karakteru dvojice pisaca: „Znate, kada su nas upućivali ovamo, u CK su rekli da sam ja previše ekspanzivan i pričljiv, a Franičević previše ćutljiv, i ako bi nas spojili zajedno i onda podelili bili bi to prava, dobra delegacija. ${ }^{\text {2 }}$

U tom periodu, krajem 1954. godine, D. Ćosić je bio 33-godišnji pisac koji je iza sebe imao zapažen književni prvenac, prvi modernistički roman posleratne jugoslovenske književnosti - Daleko je sunce (1951), o kome je u to vreme govoreno kao o prelomnoj knjizi tadašnje jugoslovenske literature i koji je bio jedna od najčitanijih knjiga tokom 1950-ih. Upravo u decembru 1954. kada je krenuo put Moskve, objavljen je njegov drugi roman Koreni, koji je kritika izuzetno pozitivno dočekala, i koji je nekoliko meseci kasnije dobio prvu Ninovu nagradu za književnost. Osim toga, ovaj bivši agitpropovac (od 1948. do 1951, kada se odlučio za karijeru profesionalnog pisca, bio je član Agitpropa Centralnog komiteta Komunističke partije Srbije) još od 1945. godine bio je narodni poslanik (prvo republički, pa savezni). Pored svojih poslaničkih obave-

\footnotetext{
${ }^{18}$ Opširnije: AJ, fond 498, Savez književnika Jugoslavije, fascikla 41, Секретарь Правления Союза Советских писателей СССP - Союзу писателей Югославии, 19. 10. 1954; Isto, Generalni sekretar Saveza književnika Jugoslavije Aleksandar Vučo - Sekretaru Uprave Saveza sovjetskih pisaca SSSR Borisu Polevoju, 6. 11. 1954; Isto, Telegram (br. 311) Borisa Poljevoja - Savezu književnika Jugoslavije, 9. 11. 1954; Isto, A. Vučo - B. Polevoju, 8. 12. 1954; „Двојица југословенских књижевника на конгресу совјетских писаца“, Борба, 6. 11. 1954, 4; Российский государственный архив литературы и искусства (РГАЛИ), Ф. 631 (Союз писателей СССР), Оп. 26, Д. 3581, Л. 2, А. Вучо - Б. Пољевоју, 6. 11. 1954; Исто, Л. 5, А. Вучо - Б. Пољевоју, 8. 12. 1954.

${ }^{19}$ П. Ј. Марковић, н.., , 404-405.

${ }^{20}$ AJ, 498-25, Generalni sekretar Saveza književnika Jugoslavije A. Vučo - Komisiji za kulturne veze sa inostranstvom, 19. 11. 1957.

${ }^{21}$ РГАНИ, Ф. 5, Оп. 28, Д. 342, Л. 32, О Югославских писателях...
} 
za, kao intelektualac angažovan u javnom životu, putovao je i držao različita predavanja širom zemlje. Od značajnih stvari iz njegove dotadašnje biografije, vredi pomenuti i posetu Golom otoku u leto 1952. godine i izveštavanje vodećih jugoslovenskih komunista o stanju na ostrvu, posle čega je poboljšan odnos prema zatvorenicima. Kako je primećeno, ta poseta ,mediteranskom gulagu“ je bila ,njegov debi na sceni velikih istorijskih događaja, na kojoj će nastupati sledećih šest decenija“. ${ }^{22}$ Iz ovih nekoliko biografskih podataka može se videti da je D. Ćosić - inače, književnik kome je politika bila usud i potreba - imao i književne i političke „kvalifikacije“ za pomenutu misiju u SSSR-u, misiju u kojoj su se, u jednom važnom periodu za normalizaciju odnosa između dve države, preplitali politički i književni motivi i ciljevi.

Prvih dana po dolasku u Moskvu (13. decembar) i po otpočinjanju Kongresa (15. decembar) D. Ćosić i M. Franičević su se držali suzdržano, naglašeno zatvoreno i zvanično. Na ovakvo njihovo držanje je svakako uticalo sve ono što se dešavalo tokom jugoslovensko-sovjetskog konflikta, a posebno jugoslovenska antisovjetska propaganda, koja je od kraja 1949. predstavljala SSSR kao svet zla, represije, neslobode, bede i siromaštva. ${ }^{23} \mathrm{O}$ njihovim unutrašnjim predstavama o SSSR-u upečatljivo svedoči „literatura“ koju je Ćosić konsultovao pripremajući se za put. U svojim zapisima on navodi da je čitao ,'Rusija iz drugog ugla' od američkog novinara i špijuna Solsberija“ i „,Povratak iz SSSR-a Andre Žida, za koga sam još kao skojevac znao da je izdajnik, iako do tada nisam nijedan njegov redak pročitao“. ${ }^{24}$ Pogledi i predubeđenja sa kojima su jugoslovenski književnici krenuli na put su na određeni način bili ,potvrđeni“ u razgovorima sa sovjetskim saputnicima u vozu. U razgovoru sa jednim podoficirom D. Ćosić je osporavao tvrdnje da je J. B. Tito ,izdajnik“, navodio da je on „,komunist“, ,,sekretar Komunističke partije“ i isticao da je Jugoslavija „socijalistička zemlja“. Prema sovjetskim dokumentima, Ćosić i Franičević su se žalili da su od saputnika u vozu mogli čuti da je ,u Jugoslaviji fašizam i Tito - fašista“. Pišući o svađi ,sa oficirima i inženjerom geodezije“ $u$ vagon-restoranu, koja je zamalo prerasla u tuču, Ćosić navodi da nakon nje ne veruje u ,jugoslovensku tezu“ po kojoj ,,posle Staljinove smrti, pritisak masa na vlast i Partiju otvara proces demokratizacije“ i da ne veruje ,da je taj proces ozbiljan posle Staljinove smrti, ako i postoji“. „Sve što se ovde na tom planu zbiva samo je 'provetravanje zagušljivih prostorija'" - beleži Ćosić. ${ }^{25}$ Navedeni razlozi su uticali na to da su približavanje sovjetskoj prestonici pratili zabrinu-

\footnotetext{
${ }^{22}$ Opširnije: Slavoljub Đukić, Čovek u svom vremenu. Razgovori sa Dobricom Ćosićem (Beograd: Filip Višnjić, 1989), 30-72; П. Ј. Марковић, „Тито и његово доба“, у: Исти, Владимир Кецмановић, Тито, поговор (Београд: Службени гласник, 2012), 160, 162; Д. Ћосић, Разговори и животопис (Београд: Филип Вишњић, 2005), 7-9, 330-334; Радован Поповић, Време писиа (Београд: Службени гласник, 2009), 14-49; М. Гаталовић, н. д., 84, 94, 123, 190, 226, 301; Коста Николић, Српска књижевност и политика 1945-1991. Главни токови (Београд: Завод за уџбенике, 2012), 266-271.

${ }^{23}$ П. Ј. Марковић, Београд између Истока и Запада 1948-1965, 122-132.

${ }^{24}$ Д. Ћосић, Пишчеви записи..., 70.

${ }^{25}$ Исто, 72, 73-74; РГАНИ, Ф. 5, ОП. 28, Д. 342, Л. 21, О Югославских писателях...
} 
tost i unutrašnji nemir („Potišten sam. Slutim šta ću doživeti i strepim od Moskve.“), kao i loše spavanje - noć pred dolazak u Moskvu Ćosić je samo ,prodremao“, a prvu noć u sovjetskoj prestonici obeležili su „užasni snovi“. Napregnutoj atmosferi doprinelo je i to što su službenici SSK zaboravili da ispune niz molbi koje su im bile saopštene odmah po dolasku u Moskvu. Takođe, D. Ćosić je bio nezadovoljan zbog toga što mu je za prevodioca dodeljena „proverena NKVD-ovka“ Nazarova, „špijunka koja radi s Perom Popivodom i Radonjom Golubovićem“. Ona je posle žalbe zamenjena Idom Markovnom Litvakovom (i na nju je jugoslovenska strana naknadno imala primedbe: ambasador Vidić je navodio da je ,žena o kojoj (je) pisala naša štampa i čiji muž (je) na robiji u FNRJ kao neprijatelj“). ${ }^{26}$ I inostrani gosti Kongresa su se u početku prema jugoslovenskim književnicima odnosili suzdržano. Tokom prvih dana za njihov sto u restoranu su hteli da sednu prvo Francuzi, a potom i Bugari, ali kada su saznali da su oni predstavnici Jugoslavije, pošli su ka drugom stolu. Čitav niz stvari je, kako beleži njihov pratilac I. Litvakova, doprinosio njihovom „daljem otuđenju“ i stvaranju utiska ,da njih hoće ovde da uvrede“. ${ }^{27}$

Zbog svega navedenog, ne čudi što se sovjetskoj strani nije činilo neobičnim da su jugoslovenski književnici bili polemički nastrojeni po nizu pitanja u vezi sa sovjetskom kulturom u kojoj je po njihovom mišljenju vladao ,ždanovizam“, koji je za njih predstavljao ,zabranjivanje svih formalnih novina, puno odsustvo slobode, stvaralaštva i t. d.“; što su se raspitivali o objavljivanju dela književnika koji su imali problema sa vlastima (Pasternak, Zošćenko, Ahmatova, Oleša); što je Ćosić stalno pravio aluzije na „,uvrede“, „,konflikt““ i slično, a Franičević prvih dana Kongresa u štampanim tekstovima referata ,podvlačio isključivo ta mesta gde se govorilo o negativnim pojavama u našoj (sovjetskoj prim. autora) književnosti“; što je Ćosić izazivački isticao kako „mi slobodno govorimo i pišemo šta hoćemo“, kako je „kod nas puna sloboda (književnih) pravaca". ${ }^{28}$ Kako bi ublažili negativan stav gostiju iz Jugoslavije i uticali na predubeđenja sa kojima su krenuli na put, domaćini su preduzeli niz koraka da „raskrave“ Ćosića i Franičevića. Tom cilju je poslužio i kulturni program organizovan van kongresnih dešavanja - posete pozorišnim predstavama, muzejima i izložbama. Gosti su vođeni na satiričnu predstavu „Sauna“ (rus. Баня). Кada su pre gledanja bili upoznati sa radnjom, Franičević je pitao da li će oštrina predstave biti umekšana. Međutim, već posle drugog čina Ćosić je komentarisao: „Kod nas ovo ne bi odobrili“; a potom je priznao da je do tada bio uveren da „,satira i socijalizam ne mogu zajedno da žive“. Čak je i izjavio da će ,insistirati“ na postavci predstave u Jugoslaviji, priznajući: „Ne, vi ste ipak širi, smeliji nego mi... Nisam mislio...". ${ }^{29}$ Pozitivan utisak su ostavljale i druge predstave. Posle odgledane „Tri sestre“, Ćosić je pribeležio: „Nikad ni s jedne pozorišne

\footnotetext{
${ }^{26}$ DA MSP RS, PA, 1955, f. 64, dos. 1, 42135, Telegram ambasadora D. Vidića - Državnom sekretarijatu za inostrane poslove FNRJ, 16. 2. 1955; Д. Ћосић, Пишчеви записи..., 75, 76-77.

27 РГАНИ, Ф. 5, Оп. 28, Д. 342, Л. 21, О Югославских писателях...

${ }^{28}$ Исто, Л. 20-22.

${ }^{29}$ Исто, Л. 35.
} 
predstave nisam izašao tako potresen. Glumci i režiser Dovženko rekli su više od Čehova o ljudima koji pate.“ Razmišljajući o aktuelnosti teme predstave, Ćosić je naveo kako ona pruža utehu i ,obećava neku nadu“ sovjetskim građanima, dodajući da to znači mnogo i njemu - ,rovašenom verniku““ ${ }^{30}$

Sličan utisak na Ćosića ostavila je i poseta Muzeju likovne umetnosti, gde je obilazak postavke namerno započeo od poslednjih sala u kojima su bile izložene slike Pikasa, francuskih impresionista i ekspresionista. To je bilo preduzeto kao „odgovor" na primedbu koju su Ćosić i Franičević izrekli po dolasku, kako u SSSR-u ,verovatno ne znaju o 'modernim' tokovima u zapadnoj umetnosti', t. j. očigledno ona nisu dostupna sovjetskim gledaocima“. Franičević je zbunjeno prokomentarisao kako je mislio da u SSSR-u ,to ne priznaju i ne izlažu“, a Ćosić je - kada se Franičević udaljio(!) - rekao pratiocu kako bi ,silno želeo podrobnije da razgovara [...] o vašoj kulturnoj politici, o umetnosti“, dodajući: „Očigledno, ja nešto nisam razumeo“. Jak utisak na Ćosića je ostavila i poseta Muzeju Majakovskog - Litvakova je napisala kako je on ,prosto drhtao od uzbuđenja“ i tražio da ponovo poseti muzej i na miru razgleda stvari i rukopise „našeg Vladimira““ 31

Sovjetska strana je nastojala da iskoristi i lične susrete rukovodstva SSK sa gostima kako bi uticala na njih. Već na jutarnjem zasedanju 17. decembra delegaciju su pozvali u Prezidijum Kongresa gde su se sa njima toplo pozdravili i razgovarali rukovodeći delatnici SSK, Poljevoj, Simonov, Surkov i Tihonov. Organizovano je i snimanje susreta, a novinar radija im se obratio molbom za intervju. Litvakova je smatrala da su oni ,bili dirnuti“. Ogroman uticaj na njih je imao susret organizovan u pauzi između kongresnih izlaganja $i$,običan i neposredan profesionalno-književnički razgovor" sa Leonidom Leonovom. Sam Ćosić beleži da je tom prilikom bio ,zbunjeno uzbuđen“. Od svih pisaca koje su sreli na Kongresu, jugoslovenski književnici su sa njim proveli najviše vremena i najviše se sa njim zbližili. Posle ovog susreta Leonov je pozvao jugoslovenske pisce kod sebe u goste, bio je i na večeri u jugoslovenskoj ambasadi, a na kraju Kongresa, na svečanoj večeri u Kremlju, on je nazdravljao Jugoslaviji i jugoslovenskoj literaturi. Duboka bliskost koju je Ćosić osećao prema Leonovu kao književniku čitajući njegova dela, produbila se posle upoznavanja i razgovora sa njim. Litvakova je pribeležila da je posle posete Leonovu „Ćosić bio tako uzbuđen da su mu ruke drhtale“, i da je kasnije rekao da „celu noć nije spavao“. Ćosić je smatrao da je Leonov, ,veliki umetnik, po mnogo čemu i častan unuk Dostojevskog“ i da je ,jedno od najdarovitijih pera savremene Rusije“. Po povratku u Jugoslaviju u Klubu književnika održao je predavanje u kome je ,sa očiglednim simpatijama“ pričao o Leonovu, a divljenje i duboko poštovanje koje je osećao prema njemu izrazio je u punoj meri člankom „Susret u Moskvi“, objavljenom u književnom časopisu Delo. ${ }^{32}$

\footnotetext{
${ }^{30}$ Д. Ћосић, Пишчеви записи..., 97.

${ }_{31}$ РГАНИ, Ф. 5, Оп. 28, Д. 342, Л. 25, 35-36, О Югославских писателях...

${ }^{32}$ Исто, Л. 21, 34-35; M. Franičević, „Gosti na govornici. Odnos prema Jugoslaviji“; D. Ćosić, „Susret u Moskvi“, 8-18; Д. А, „Прва НИН-ова „Награда критике“ од 500.000 динара додељена је Добрици Ћосићу“, НИН, 13. 2. 1953, 9; S. Đukić, Čovek u svom vremenu..., 84.
} 
Ambasador Vidić je 23. decembra javljao kako „naše primaju spolja galantno i gostoprimivo“. Franičević je po povratku u Jugoslaviju pisao kako su Ćosić i on primljeni „veoma gostoljubivo“, kako je organizacija bila „veoma dobra“ i da su videli „sve ono što smo izjavili da želimo vidjeti““. ${ }^{33}$ Ovakav odnos Sovjeta izazvao je promenu pre svega kod D. Ćosića. U tom smislu karakteristična je njegova reakcija prema kraćem intervjuu o ruskoj i sovjetskoj književnosti koji je dao prvih dana boravka u Moskvi. Svega nekoliko dana kasnije pitao je ako intervju još nije predan u štampu da ga uzme nazad kako bi napisao novi, zbog toga što mu se „ta izjava sada čini žalosnom i manje vrednom“. Tom prilikom je naveo da je ,ceo njegov život, sva njegova borba povezana upravo sa sovjetskom literaturom“, da su „Gorki, Majakovski, sovjetska književnost prerasli pojam 'književnosti' i da su kod nas postali pomoćnici u životu i borbi“. Napomenuo je i kako „vi čak nemate predstavu da su se sve ove godine, kada vi niste hteli ni da čujete za nas, kod nas objavljivane skoro sve vaše knjige. Kod nas su objavljena puna sabrana dela Gorkog. Kod nas je objavljen novi prevod Majakovskog. Ja hoću i o tome da govorim.“" Međutim, pošto je intervju već bio preveden, Ćosić nije hteo da ga povlači. ${ }^{34}$

Na sovjetskoj strani je primećeno da je Ćosića, kao „više osećajnijeg čoveka, neposrednijeg i temperamentnijeg“, tokom trećeg dana Kongresa „zaprepastila sloboda i otvorenost kritičkih primedbi referenata koji su istupali u diskusiji“. Litvakova piše kako se posle govora književnika Vilisa Lacisa Ćosić „odjednom naglo okrenuo i pitao: 'Znači kod vas može tako? “ Pošto nisu znali ruski jezik, jugoslovenski književnici su sadržaj diskusije pratili preko I. M. Litvakove, koja im je u pauzama „podrobno izlagala svaki govor“. Sam Ćosić je o tome pribeležio: „Beležim ponešto, koliko mi prevodilac prevede.“ Po pitanjima koja je Ćosić postavljao bilo je primetno da je imao negativnu predstavu o SSSR-u kao državi u kojoj je diskusija nemoguća. Pitao je: „A Šostakoviča kod vas izvode“; interesovao se šta su „radili sa piscima i knjigama ako je knjiga napadana“; tražio je pojašnjenje u vezi sa tim što su dela V. Panove posle objavljivanja u časopisu i kritike bila objavljena u zasebnoj knjizi („A ako pisca napadaju kada on objavljuje u časopisu, njegova knjiga se svejedno objavljuje?"). Posle odgovora koje je dobio, Ćosić je ponovo izgovorio: „Nisam znao da kod vas može...". ${ }^{35}$ Iz jugoslovenske ambasade su tokom Kongresa javljali da su „diskusije slobodnije, atmosfera liberalnija“, da je „niz književnika kritikovao dosadanju dirigovanost na polju književnog stvaralaštva“". ${ }^{36}$

U objavljenim zapisima D. Ćosića nalaze se beleške o nizu kritičkih istupanja sovjetskih pisaca, ali se iz njih ne vidi Ćosićeva promena stava o prilikama u SSSR-u i o liberalizaciji odnosa (pišući o istupanju Ilje Erenburga i nizu

\footnotetext{
${ }^{33}$ DA MSP RS, PA, 1954, f. 86, dos. 13, 416867, Telegram D. Vidića Državnom sekretarijatu za inostrane poslove FNRJ, 23. 12. 1954; M. Franičević, „Oko kongresa“.

${ }^{34}$ РГАНИ, Ф. 5, Оп. 28, Д. 342, Л. 21, 28-29, О Югославских писателях...

${ }^{35}$ Исто, Л. 22; Д. Ћосић, Пишчеви записи..., 83.

${ }^{36}$ DA MSP, PA, 1954, f. 86, dos. 13, 416867, Telegram D. Vidića Državnom sekretarijatu za inostrane poslove FNRJ, 23. 12. 1954
} 
kritičkih primedbi koje je on izneo, Ćosić je smatrao da je to „dokumenat [...] više o Ilji, no o novoj, poststaljinskoj politici“"). Ni po povratku u Jugoslaviju nije govorio o tome, već mu je osnovni utisak bila „kriza sovjetske kulture““37 Verovatno je da je on - kao neko ko je kritički gledao na normalizaciju odnosa dve države i domete promena u SSSR-u - postupao po određenim instrukcijama dobijenim pred polazak na put ili tokom svakodnevnih konsultacija u jugoslovenskoj ambasadi. ${ }^{38}$ Ova mogućnost se čini izvesnom kada se pogledaju njegove reči upućene Litvakovoj u kojima navodi da mu se čini da će on biti ,prvi socijalistički realista u Jugoslaviji““ ${ }^{39}$ Kada se ima u vidu da je tokom godina sukoba vodio „književnu i ideološku borbu protiv pristalica socijalističkog realizma, kao poetike staljinizma“ i zalagao se „za novu modernu književnost“; kao i da je, prema njegovim zapisima sa Kongresa, socrealizam karakterisao kao „pragmatične, partijske laži“ koje su okivale „maštu i misao“ sovjetskim književnicima i nadao se da će doći do obračuna sa tom doktrinom - jasno je da on to nije zaista mislio, već je govorio takve stvari radi stvaranja prisnije atmosfere u kontaktima i pokazivanja „dobre volje“ sa jugoslovenske strane. ${ }^{40}$

Ostavljajući po strani pitanje da li je reč o iskrenoj promeni ili taktici D. Ćosića da bi se prenela određena poruka, primetno je da je sovjetska strana uočavala kako se menjalo njegovo držanje tokom Kongresa i iz toga i njegovih izjava izvlačila zaključke i preduzimala određene korake. Litvakova je pažljivo beležila sve njegove komentare u kojima je izražavao čuđenje i iznenađenost onim što vidi. ${ }^{41}$ Imajući kratke, ali svakodnevne kontakte sa jugoslovenskim piscima i sekretari SSK su primećivali da se njihovo držanje tokom Kongresa „oštro izmenilo“, da su ,postali otvoreniji“. Referišući CK KPSS o njihovom boravku, oni su navodili da se „u ličnim razgovorima kod njih ispoljavalo po svoj prilici iskreno, a moguće i unapred smišljeno žaljenje o zategnutim odnosima među našim državama i o gubitku osećanja prijateljstva“ i o tome da su oni ,počeli direktno i otvoreno govoriti o neophodnosti obnavljanja prijateljskih kulturnih veza“. ${ }^{42}$

Ključni prelom u držanju Ćosića desio se četvrtog dana Kongresa, 19. decembra, u vezi sa pitanjem o govoru jugoslovenskih književnika. U razgovoru nasamo sa Litvakovom Ćosić je ismejao prethodno dugačko, teoretsko obrazlaganje Franičevića, kao odgovor na konkretno pitanje da li hoće da govore na Kongresu, nazvavši to „profesorskim glupostima“. Zatraživši da razgovara „kao komunista sa komunistom“ navodio je da su oni za sve na Kongresu „samo 'progresivni demokratski pisci'“, izgovarajući te reči sa ,izvesnim prezrenjem“ i dodajući: „Pa vi još nijednom niste nas nazvali 'druže' (tavarišć), nego sve zaobilazite oko te reči kao oko vrelog kotla samo da ga ne dotaknete. A mi

\footnotetext{
${ }^{37}$ М. Милорадовић, н. д.; Д. Ћосић, Пишчеви записи..., 83-86, 91, 93-96.

${ }^{38}$ Исто, 66-67, 74-75, 92-93.

${ }^{39}$ РГАНИ, Ф. 5, Оп. 28, Д. 342, Л. 23, О Югославских писателях...

40 Д. Ћосић, Пишчеви записи..., 87-88, 92; Д. Ћосић, Пријатељи, прир. Ана Ћосић-Вукић (Београд: Политика, 2005), 143, 144.

${ }^{41}$ Na primer: РГАНИ, Ф. 5, Оп. 28, Д. 342, Л. 25, О Югославских писателях...

42 РГАЛИ, Ф. 631, Оп. 26, Д. 3582, Л. 1, Сурков А.А. и Полевой Б.Н. - в ЦК КПСС, 6. 1. 1955.
} 
smo komunisti. Razumete - komunisti. I ja hoću vama da kažem 'drugovi', i ja se ponosim pre svega time što sam ja komunista i što sam doputovao iz zemlje koja hoće da gradi socijalizam." Ukazao je na to da bi u slučaju da govori mogao da priča „samo o tome kako se može rasčistiti put između nas“ i da je on komunista koji se bori za pobedu socijalizma, ali bi to ,izazvalo nepotrebne komplikacije“ i morale bi da budu pomenute stvari „koje su nas razdvajale“. Pominjući da on nije diplomata, već pisac, naveo je da je bolje da M. Franičević govori. ${ }^{43}$ Ove Ćosićeve reči su od strane Litvakove bile prenete rukovodiocima SSK, kao i briga jugoslovenskih književnika u koji lager će ih Tihonov ,ubrojati“" u najavljenom referatu o inostranoj književnosti (prema rečima Franičevića pitanje da li će govoriti ili ne na Kongresu ,zavisi više od Tihonova, nego od nas"). Zahvaljujući tome u referat Tihonova su bile uključene pozitivne reči o književnosti jugoslovenskih naroda, koje su poslužile kao katalizator daljih kontakata. U referatu izgovorenom na Kongresu deo o jugoslovenskoj književnosti je naveden, kako Litvakova navodi „krajnje srećno“, između Poljske i Kine (u govoru objavljenom narednog dana u Literaturnoj gazeti FNRJ je bila pomenuta posle Zapadne Nemačke). Kratko nezadovoljstvo izazvalo je to što među žrtvama fašizma „nisu pomenuti heroji Jugoslavije - pisci Cesarec i Kovačić“, ali je to bilo ispravljeno u štampanoj verziji referata. ${ }^{44}$ Reakcija gostiju iz Jugoslavije bila je spontana. Oba delegata su ,uzbuđeno prišli Prezidijumu i skoro sa suzama u očima govorili o svojoj radosti“. Ćosić je rekao: „Vi možda ne razumete koliko je to nama važno i drago." ${ }^{45}$ Posledica ovakvog odnosa bila je saglasnost jugoslovenskih pisaca - posle konsultacija u ambasadi - da govore na Kongresu. ${ }^{46} \mathrm{U}$ govoru održanom 24 . decembra Franičević je, pored prilika u jugoslovenskoj književnosti i slanja poruka u duhu ,aktivne koegzistencije“, istakao i kako su ,dela velikih ruskih i sovjetskih književnika“ u Jugoslaviji „kod kuće kao i u Sovjetskom Savezu“. 47

Dan posle istupanja Franičevića gosti su preneli sekretarima SSK poziv od ambasadora Vidića da dođu na „drugarsku večeru“ u ambasadu. Poziv je bio propraćen molbom za dolazak (,zaboga, dođite“) i naglašeno je da ,vi ne shvatate koliko je to važno za nas i za uzajamne odnose naših država“" (Franičević). Ćosić je isticao: „Ako vi zaista volite naš narod i hoćete da naši narodi budu prijatelji, jako vas molim - dođite, vi ne shvatate kako je to za nas važno!“ Posle konsultacija u aparatu CK KPSS, glavni rukovodioci SSK, četiri

\footnotetext{
${ }^{43}$ РГАНИ, Ф. 5, Оп. 28, Д. 342, Л. 23-24, О Югославских писателях...

${ }^{44}$ Исто, Л. 30; „Тихонов о југословенској књижевности“, Борба, 25. 12. 1954, 4; M. Franičević, „Gosti na govornici. Odnos prema Jugoslaviji“.

${ }^{45}$ РГАЛИ, Ф. 631, Оп. 26, Д. 3582, Л. 1-2, Сурков А.А. и Полевой Б.Н. - в ЦК КПСС, 6. 1. 1955.

${ }^{46}$ РГАНИ, Ф. 5, Оп. 28, Д. 342, Л. 31-32, О Югославских писателях...

${ }^{47}$ „Полет југословенске књижевности је у складу са социјалистичким демократизмом. Реч Марина Франичевића“, Борба, 26. 12. 1954, 6; „Изложение выступления М. Франичевича“, Литературная газета, 25. 12. 1954, 4; Второй всесоюзный съезд советских писателей. 15-26 декабря 1954 г. Стенографический отчет (Москва: Советский писатель, 1956), 556-557.
} 
sekretara Uprave - Surkov, Simonov, Leonov i Poljevoj, posetili su jugoslovensku ambasadu. Iako je pri dočeku bila naglašena ljubaznost, on je - prema svedočanstvu sekretara SSK - bio zvaničan. Međutim, zvaničnost je u potpunosti nestala ,za stolom“: „Zdravice za prijateljstvo naših naroda, za obnavljanje nekadašnjih veza, za to da se jedni drugima obraćamo ne sa 'gospodo', nego 'drugovi', prihvatane su od svih vrlo toplo.“ Prijemu je prisustvovao i vođa jugoslovenske trgovinske delegacije Mijalko Todorović (zbog njega su Ćosić i Franičević i insistirali da se sekretari SSK odazovu pozivu), za koga su Sovjeti navodili da se jedini držao „dosta suzdržanije od ostalih“, iako je „,u toku razgovora za stolom nazdravio za obnavljanje prijateljskih odnosa“. Ambasador Vidić je u toku večere ,pokazao najživlje interesovanje za obnovu kulturnih veza“. Sekretarima SSK je predočeno da tokom ,godina zategnutih odnosa“ sovjetske knjige nisu povlačene iz biblioteka, da je sovjetska književnost, iako u ograničenim tiražima, objavljivana, da su u pozorištima ,igrane ruske pozorišne predstave“. Pomenuto je da su najveći uspeh među savremenim sovjetskim predstavama imali „Pauci“ Sergeja Mihalkova, koji su davani „pod provokativnim nazivom 'Sami o sebi'", ali su oni skinuti sa repertoara, što je Vidić okarakterisao kao pokazatelj „popravljanja odnosa“. Tokom večere Ćosić je u porivu otvorenosti (mada sekretari SSK nisu isključivali da je to možda bila ,unapred promišljena namera“"), rekao da Franičević i on nisu samo pisci koji su došli na Kongres, već su i „misija dobre volje“ koja ima za cilj da sazna „koliko iskreno sovjetski ljudi misle o zbližavanju i o obnovi dobrih odnosa" (slično ovome, Franičević je pisao kako su oni krenuli na put da bi videli „na svoje oči da li je tamo ipak nešto krenulo i da li zaista sa Kremlja puše drukčiji vjetar"). Na pitanje Sovjeta „šta je pokazala misija dobre volje“, Ćosić je odgovorio da su „nas svuda dočekivali kao drugove“ $\mathrm{i}$ da je Kongres „nama mnogo pokazao, vrlo mnogo““. ${ }^{48}$ Po srdačnoj atmosferi za vreme večere - o kojoj su rukovodioci SSK morali da izveste - moguće je da je ova poseta uticala i bila svojevrsna uvertira za iznenadan dolazak gotovo čitavog sovjetskog rukovodstva u jugoslovensku ambasadu nekoliko dana kasnije, 27. decembra.

Izvori pokazuju kako su i pre razgovora u ambasadi domaćini doživljavali goste ne samo kao pisce, već i kao nekoga ko pažljivo skuplja utiske o kojima će po povratku iz Moskve referisati. Na sovjetskoj strani su stekli utisak da su oni tokom boravka pažljivo upijali različite informacije (poseta pozorištima, muzejima, Moskovskom državnom univerzitetu, metrou, susreti sa piscima, studentima, profesorima, razgovori na samom Kongresu...). Litvakova je primećivala da su se interesovali za stanje u sovjetskim republikama, da su se detaljno raspitivali o svakoj od njih, o njihovim književnostima i ,indirektno“ o stepenu njihove samostalnosti. Kada se čitaju Ćosićevi zapisi - zapažanja i način na koji ih je beležio - vidi se da je on na put krenuo ,širom otvorenih očiju“". Iz izveštaja Litvakove se vidi da je, za razliku od zatvorenijeg Franičevića, često postavljao pitanja, tražio dodatna pojašnjenja, interesovao se za detalje, a ona sama

${ }^{48}$ РГАЛИ, Ф. 631, Оп. 26, Д. 3582, Л. 2-3, Сурков А.А. и Полевой Б.Н. - в ЦК КПСС, 6.1.1955; M. Franičević, „Drugo putovanje u SSSR“. 
navodi da on ima „ogromnu želju da razume, sazna“. ${ }^{49}$ Izvori pokazuju i kako je postepeno politička komponenta u razgovorima dobijala sve veći značaj, pa u određenoj meri i odnela prevagu nad pitanjima književnosti i kulture. Na sovjetskoj strani su uočavali da Ćosić - „ubeđeni pristalica Tita“, uveren u to da se u „Jugoslaviji gradi socijalizam“ - ne propušta u razgovoru nijednu zgodnu priliku da naglasi da je on „komunista i da je komunizam - jedina stvar njegovog života“. Pored njegovih izjava koje su bile direktno političke prirode, i u njegovim rečima koje su se odnosile na književnost tražene su političke poruke. Govoreći o raspravama koji se odnose na književna pitanja, Ćosić je jednom prilikom rekao „mi ćemo se još prepirati“, dodajući: „Samo, razumete, kod nas sa vama ta rasprava je na vrlo visokom nivou. Vi umete da odbacite, pređete preko ličnih uvreda, preko sitnih stvari, a mi... Ne, ja sebi nisam tako predstavljao...". Za poslednje reči Litvakova je navodila da su ,tako rečene, da se mogu razumeti kao nešto što se odnosi samo na književnost, ali i šire". ${ }^{50}$

Iz izvora se vidi da su obe strane u razgovorima nastojale da izbegnu sporna pitanja. Pri razmatranju problema o istupanju na Kongresu, Ćosić je Litvakovoj ponovo govorio o tome kako bi ,sada više nego ikada hteo isto tako kao i Bugari i Mađari da govori o svom narodu koji gradi socijalizam i o svojoj želji da svi mi vidimo u njemu pisca-komunistu“, ali bi to po njegovom mišljenju zvučalo kao „nepotrebno izazivanje“ $i$, ,u sadašnjem trenutku moglo da bude samo štetnim“. Zaključivao je: „Među nama je još mnogo neraščišćenog. I mi ne treba da rešavamo to. Ostavimo to političarima. Mi smo doputovali i time pokazali svoju dobru volju. ${ }^{\text {(51 }}$ Kada je na prijemu u ambasadi Vidić pomenuo „zlosrećnu knjigu Maljceva“ (,Jugoslovenska tragedija“), sa sovjetske strane su replicirali pomenuvši „dve odgovarajuće knjige, objavljene u Beogradu i Zagrebu“, na šta se ambasador nasmejao i ,predložio da ispiju za to da se uskoro sve to zaboravi““ ${ }^{52} \mathrm{~S}$ druge strane, sovjetski pisci su - u skladu sa zvaničnim sovjetskim stavom - isticali: „Po mogućnosti što prije zaboraviti što je bilo među nama, jer su ionako uklonjeni 'oni koji su za to krivi'“; navodili da „za njih to nije bilo nikakvo stvarno razmimoilaženje, nego samo svađa među braćom“, ,jako često" su pominjali i „akcentirali“ slovenstvo; i nazdravljali ,'herojskom jugoslavenskom narodu' i našoj (jugoslovenskoj - prim. autora) literaturi“ “. ${ }^{53} \mathrm{U}$ razgovorima je sa sovjetske strane isticano kako je ,zajedničkog - značajno više, nego onoga što razdvaja“, a nastojali su i da „svaku, čak i kritičku, reč“ Jugoslovena dočekaju sa „,drugarskom pažnjom“, što je goste, kako navodi Litvakova, činilo ,zbunjenim“. 54

Ćosić je do kraja Kongresa ostao dosledan u svojim izjavama. Na prijemu u Kremlju poslednjeg dana Kongresa (26. decembra), imao je nekoliko

\footnotetext{
49 Д. Ћосић, Пишчеви записи..., 71-97; РГАНИ, Ф. 5, Оп. 28, Д. 342, Л. 22, 25, 28, 39, О Югославских писателях...

${ }^{50}$ Исто, Л. 19, 27.

${ }^{51}$ Исто, Л. 31.

52 РГАЛИ, Ф. 631, Оп. 26, Д. 3582, Л. 2-3, Сурков А.А. и Полевой Б.Н. - в ЦК КПСС, 6. 1. 1955.

${ }^{53}$ M. Franičević, „Gosti na govornici. Odnos prema Jugoslaviji“‘.

${ }^{54}$ РГАНИ, Ф. 5, ОП. 28, Д. 342, Л. 31, О Югославских писателях...
} 
komentara u vezi sa normalizacijom odnosa. Kada su u Prezidijum ušli Maljenkov i Hruščov zajedno sa Molotovom, Ćosić je izdvojio prve: „U njih dvojicu ja mnogo verujem. [...] Oni će umeti da urade tako da se sve među nama vrati na staro. Dobro je što oni nisu potpisali pismo." Poslednje je bilo očigledna aluzija na Molotova i poznata pisma iz 1948. godine. A kada su prilikom izgovaranja zdravica Jugosloveni pomenuti posle predstavnika zemalja ,narodne demokratije“, Ćosić se nasmejao i prokomentarisao: „Ništa, doći će vreme da nas ponovo počnu da pominju prve.“ Podjednako upečatljive su bile i izjave sovjetskih pisaca, koji su navodili izreku: „Ko staro pamti - da mu izbiju oko“ (iste reči je koristio Hruščov tokom posete Jugoslaviji 1955. godine). Komentarišući razgovore na prijemu, Ćosić je pomenuo kako je „,više od svega ostavila utisak 'široka' spremnost naših drugova da 'pređu preko uzajamno nanesenih uvreda' i kako pisci 'ipak' mogu mnogo da urade u toj stvari“. Dodao je i: „Vi znate, postoje dve diplomatije - diplomatija uljudne učtivosti i diplomatija vesele iskrenosti. Poslednja je za nas sa vama najbolja, najubedljivija. Njom do savršenstva vladaju Surkov i Poljevoj. Ja njih mnogo volim. ${ }^{655}$

Tokom boravka u SSSR-u jugoslovenski književnici su u razgovorima sa sovjetskim predstavnicima razmatrali niz konkretnih pitanja u vezi sa obnovom kulturnih veza dve države - objavljivanje antologije jugoslovenske poezije, prevođenje dela jugoslovenskih književnika na ruski, informisanje sovjetske javnosti o kulturnom životu u Jugoslaviji i o ,novoj jugoslovenskoj književnosti“ putem objavljivanja članaka u časopisima posvećenim pitanjima kulture $\mathrm{i}$ književnosti. Ćosić se u Moskvi i Lenjingradu interesovao i za mogućnost dobijanja kopija „starih srpskih rukopisa i knjiga“. Dogovorena je - na uzajamnom principu - i razmena književnih časopisa i najznačajnijih knjiga između saveza književnika dve države. ${ }^{56}$ Pored toga, Ćosić i Franičević su u Moskvi imali nekoliko susreta sa stručnim krugovima. Zajedno sa učesnicima Kongresa iz slovenskih država učestvovali su u susretu sa studentima i profesorima Katedre slovenskih jezika Moskovskog državnog univerziteta. Posetili su i Institut slavistike Akademije nauka SSSR i sa njegovim saradnicima razgovarali o jugoslovenskoj književnosti. ${ }^{57}$

\footnotetext{
${ }^{55}$ Исто, Л. 36-37; А. Б. Едемский, н. д., 468. Za razliku od Franičevića koji se krajem decembra vratio u Jugoslaviju, Ćosić se zadržao u SSSR-u još nedelju dana koje je proveo u Lenjingradu. Boravak u gradu na Nevi je bio ispunjen obilascima muzeja i izložbi, gledanjem baleta i opere, susretima sa piscima, posetama bibliotekama. Opširnije o Ćosićevom boravku u Lenjingradu: РГАЛИ, Ф. 631, Оп. 26, Д. 3583, Л. 1-10, Дневник Брагина Юрия Ал., сопровождающего югославского писателя Добрицы Чосича.

${ }^{56}$ РГАНИ, Ф. 5, Оп. 28, Д. 342, Л. 36, О Югославских писателях...; РГАЛИ, Ф. 631, Оп. 26, Д. 3582, Л. 3-4, Сурков А.А. и Полевой Б.Н. - в ЦК КПСС, 6. 1. 1955; Исто, Д. 3583, Л. 9 , Дневник Брагина Юрия Ал., сопровождающего югославского писателя Добрицы Чосича; DA MSP, PA, 1955, f. 63, dos. 5, 18872, Kulturna i naučna saradnja sa istočno-evropskim državama. Jugoslavija-SSSR; Isto, f. 65, dos. 6, 41046, Bogdan Osolnik - Državnom sekretarijatu za inostrane poslove FNRJ, 20. 1. 1955; Isto, 46894, Dobrivoje Vidić - Državnom sekretarijatu za inostrane poslove FNRJ, 20. 5. 1955; M. Franičević, „Gosti na govornici. Odnos prema Jugoslaviji“.

57 РГАНИ, Ф. 5, ОП. 28, Д. 342, Л. 33, О Югославских писателях...; „Славянские писатели в гостях у студентов МГУ“, Литературная газета, 28. 12. 1954, 1; РГАЛИ, Ф. 631, Оп. 26 ,
} 
Boravak delegacije jugoslovenskih pisaca na Kongresu i razgovori sa Ćosićem i Franičevićem pomogli su rukovodstvu SSK da formuliše niz predloga za razvoj kulturnih veza sa Jugoslavijom. Ti predlozi su bili upućeni sovjetskom rukovodstvu već 6 . januara 1955 . U opreznoj formi („mi mislimo da bi bilo pravilno, naravno, ako vi delite naše mišljenje"), A. Surkov i B. Poljevoj su pisali o važnosti sledećih stvari: 1) „Pojačati odmah kulturne veze između takvih organizacija kao što su književnici, slikari, umetnici, a možda i putem VOKS-a kao celine“; 2) izaći u susret želji delegacije izraženoj tokom „poseta književnih muzeja" da dobiju fotokopije starih izdanja srpskih i hrvatskih knjiga uništenih u Narodnoj biblioteci 1941. godine; 3) hitno ,izdati u jednom od obimnih časopisa jedno od najvrednijih novih dela bilo kog jugoslovenskog autora, objaviti članak o novoj jugoslovenskoj literaturi i objaviti jednu-dve od najdoličnijih knjiga“. Među ostalim predlozima nalazili su se i obnavljanje izvođenja predstave „Gospođa ministarka“ kao „vrlo popularne u Jugoslaviji, klasične pozorišne predstave“, koja je „svojevremeno sa uspehom igrana u Moskvi“ i postavljanje jedne od novih pozorišnih predstava, na primer „Glembajeva“ Miroslava Krleže. Takođe, pomenuto je prikazivanje „na sovjetskim ekranima jednog jugoslovenskog filma, ako se među njima nađu valjani i dolični“ “. ${ }^{58}$ Iako sovjetska svedočanstva o reakciji u Jugoslaviji na Drugi kongres sovjetskih književnika (Sovjeti su bili nezadovoljni izjavom za štampu M. Franičevića datoj po povratku sa Kongresa), koja se nalaze u drugim izvorima, nisu davala osnova za optimizam, važnost ove beleške na predstojeći razvoj kulturnih veza Beograda i Moskve teško je preceniti..$^{59}$

Reakcija sovjetskog rukovodstva na ove predloge bila je pozitivna i brza. ${ }^{60}$ Pitanje nabavke i prikazivanja jugoslovenskih filmova rešeno je, kao što smo pomenuli, krajem 1954. nezavisno od boravka jugoslovenskih književnika na Kongresu. Što se drugih stvari tiče, sovjetska strana je relativno brzo upoznala čitaoce sa prilikama u jugoslovenskoj književnosti i kulturi. U prvom broju novopokrenutog časopisa Inostrana književnost (rus. Иностранная литература), objavljena je pesma Branka Ćopića „Oj, đevojko, dragaj dušo moja...“ (prevedena pod naslovom „Kozaračko kolo“), a Ćopić je čitaocima predstavljen kao „,istaknuti savremeni jugoslovenski pesnik i pisac, autor nekoliko knjiga pesama, romana“" ${ }^{61} \mathrm{U}$ sledećem broju tog časopisa dat je širi osvrt na prilike u jugoslovenskoj kulturi. ${ }^{62}$ Zamenik urednika Inostrane književnosti Sava Dangulov je u

Д. 3580, Л. 1-14, Стенограмма беседы представителей Института славяноведения АН СССР с югославскими писателями 28 декабря 1954 г.

${ }^{58}$ РГАЛИ, Ф. 631, Оп. 26, Д. 3582, Л. 4-5, Сурков А. А. и Полевой Б. Н. - в ЦК КПСС, 6. 1. 1955.

${ }^{59}$ РГАНИ, Ф. 5, Оп. 28, Д. 342, Л. 57-59, Обзор югославских газет с 1 по 21 января 1955 года; „Kongres sovjetskih pisaca u očima jugoslavenskog delegata M. Franičevića. Odgovori na pitanja naše redakcije“; „Марин Франичевић о совјетској књижевности“.

${ }^{60}$ РГАНИ, Ф. 5, Оп. 17 (Отдел науки и культуры ЦК КПСС), Д. 536, Л. 8, А. Румянцев, Б. Пономарев - в ЦК КПСС, 8. 4. 1955.

${ }_{61}^{61}$ Бранко Чопич, „Хоровод козарский“, Иностранная литература, Но. 1, (1955), 97-98, 215.

62 „Из месяца в месяц (хроника). Югославия“, Исто, Но. 2, (1955), 286-287. 
razgovoru sa jugoslovenskim diplomatama u Moskvi navodio da oni ,žele da se u časopisu odrazi prijateljstvo između naših naroda“ i da zbog toga ,za svaki broj spremaju nešto o Jugoslaviji“", da ih pored književnosti interesuje i pozorište, muzički život i kulturni život uopšte. ${ }^{63}$ Štampanju dela jugoslovenske književnosti pristupila je i redakcija časopisa Novi svet (rus. Новый мир), која је objavila prevod dela Vjekoslava Kaleba i Branka Ćopića. ${ }^{64} \mathrm{U}$ šestom broju časopisa Sloveni (rus. Славяне) objavljen je članak „Iz istorije rusko-srpskih literaturnih veza“ u kome se isticala ,tradicionalna povezanost jugoslovenskih naroda sa Rusijom i blagotvorni uticaj kojeg su izvršili ruski klasici na jugoslovensku književnost". Sovjetska štampa je detaljno pratila i gostovanje jugoslovenskih operskih solista u SSSR-u, a u intervjuima sa njima su doticana i pitanja o muzičkom i pozorišnom životu u Jugoslaviji. Pisano je i o jugoslovenskim filmovima i ,ogromnom napredku kojeg je postigla jugoslovenska filmska proizvodnja“. U Centralnom domu književnika u Moskvi 24. juna 1955. održano je Veče jugoslovenske poezije. ${ }^{65}$ Krajem jula 1955. u izdanju SSK, Književnim novinama (rus. Литературная газета), objavljen je i članak u kome je data karakteristika savremenih procesa u jugoslovenskoj književnosti i pojedinim autorima (Ćosićeva dela, kao i sam pisac, visoko su ocenjena). ${ }^{66}$ Krajem 1955. jugoslovenska ambasada je izveštavala da sovjetska štampa na kulturnom planu ističe ,napredak na svim linijama“ u FNRJ i izveštava o povećanju broja pozorišta, biblioteka i škola. ${ }^{67}$

Ozbiljno se pristupilo i pitanju prevođenja i izdavanja književnih dela iz Jugoslavije - tražene su sugestije, sastavljani su spiskovi potencijalnih dela za objavljivanje i u diskusijama su detaljno razmatrane knjige jugoslovenskih pisaca. ${ }^{68}$ Podaci o prevođenju jugoslovenskih književnih dela u inostranstvu pokazuju da su tokom 1955. u Sovjetskom Savezu objavljene sledeće knjige: Gorski vijenac Petra II Petrovića Njegoša, izabrane pesme France Prešerna, Seljačka buna Augusta Šenoe; u izboru pesama Poezija zapadnih i južnih Slovena objavljeni su prevodi nekih pesama, a u Kijevu je publikovana antologija Srpske narodne poezije. Narednih godina ovaj trend je nastavljen. U toku 1956. prevedeni su Na Drini ćuprija i izabrane pripovetke Iva Andrića, iza-

${ }^{63}$ DA MSP, PA, 1955, f. 64, dos. 4, 415304, Razgovor sa zamenikom urednika časopisa Inostrana literatura, Dangulovim.

${ }^{64}$ Векослав Калеб, „Слезы“, Новый мир, Но. 7, (июль 1955), 134-148; Б. Чопич, „Тень и бык“, Исто, 149-151.

${ }^{65}$ DA MSP, PA, 1955, f. 62, dos. 14, 49869, Pregled pisanja sovjetske štampe i časopisa o Jugoslaviji od dana objavljivanja odluke sovjetske vlade o odlasku na razgovore u Beograd, 10. 7. 1955; Isto, f. 65, dos. 7, 48656, Informacija o „Večeri jugoslavenske poezije“ održane 24. juna 1955. u Centralnom domu književnika u Moskvi, D. Rožman.

${ }^{66}$ Ю. Гаврилов, „Заметки о литературе Югославии“, Литературная газета, 26. 7. 1955, 4.

${ }^{67}$ DA MSP, PA, 1955, f. 62, dos. 3, 416602, Tekući politički izveštaj Ambasade FNRJ u Moskvi, 6. 12.1955.

${ }^{68}$ РГАНИ. Ф.5, Оп.17. Д.536. Л. 8, А. Румянцев, Б. Пономарев - в ЦК КПСС, 8. 4. 1955; РГАЛИ, Ф. 631, Оп. 26, Д. 3585, Стенограмма заседания югославского актива Иностранной комиссии ССП 21. 12. 1955; DA MSP, PA, 1955, f. 64, dos. 4, 415304, Zabeleška o razgovoru sa zamenikom ministra kulture Nazarovim 11.11.1955, B. Osolnik. 
brana dela Branislava Nušića, pripovetke Radoja Domanovića, objavljena je antologija Jugoslovenske pesme, pripovetke Alekse Mikića (Sunčana obala), kao i Daleko je sunce D. Ćosića. ${ }^{69}$

Oživotvoreni su i drugi predlozi Surkova i Poljevoja od 6. januara 1955. Početkom aprila 1955. CK KPSS-a je referisano da rukovodstvo moskovskog „Pozorišta Mossovjeta“ (rus. Театр им. Моссовета) planira u jesen da obnovi izvođenje „Gospođe ministarke“, a da Ministarstvo kulture SSSR-a ,izučava pitanje o mogućnosti izvođenja drugih pozorišnih predstava jugoslovenskih dramaturga“. U novembru 1955. počelo je izvođenje „Gospođe ministarke“, a pripreman je i Nušićev „Dr“. Od novembra 1955. na sceni moskovskog pozorišta Vahtangova izvođena je i predstava „Aleko Dundić“, a u toku godine Sovjeti su tražili partituru „Ohridske legende“ i odlučili da je postave. Bez pažnje nije ostalo ni interesovanje D. Ćosića o izradi i dobijanju „fotokopija retkih knjiga jugoslovenskih autora koje imaju u SSSR-u, za beogradsku akademiju nauka“. Činovnici Akademije nauka SSSR-a su dobili nalog da uvaže tu molbu ,pri sastavljanju plana širenja naučnih veza između AN SSSR i jugoslovenskih akademija“" 70

Što se tiče Ćosića, krajem januara 1956. Izdavačko preduzeće inostrane književnosti predalo je u štampu, u prevodu A. Romanenka, njegov roman „Daleko je sunce“، ${ }^{71}$ U proleće 1956. taj roman je, u prevodu D. Žukova, u dva dela objavljen i od strane časopisa „Roman-novine“ (rus. Роман-газета) sa tiražom od pola miliona primeraka (simbolično, u istom tiražu i u istom izdanju u oktobru 1952. bio je objavljen kontroverzni roman O. Maljceva „Jugoslovenska tragedija“). ${ }^{72}$ Krajem 1956. na jugoslovenskoj strani nisu imali primedbe na dela koja su prevođena u SSSR-u, ali su smatrali da je ,kao celina, ceo plan [...] zastareo i manje-više šablonski“، ${ }^{73} \mathrm{U}$ vezi sa tim i Ćosićem, interesantno je pomenuti da su jugoslovenske diplomate u Moskvi krajem 1955. godine primećivale da je ,od posleratnih stvari“ za prevođenje planirano „samo Ćosićevo: Daleko je sunce“" 74 Pišući u maju 1956. kako se u SSSR-u radi na sprovođenju „,̌irokog upoznavanja sovjetskih čitalaca sa jugoslovenskom literaturom“, B. Poljevoj je kao primer naveo da se tih dana u fabrici „Kompresor“ organizuje

${ }^{69}$ AJ, 498-24, Spisak jugoslovenskih književnih dela prevedenih u inostranstvu 1945-1958; Isto, Dela prevedena na strane jezike; Isto, Spisak jugoslovenskih dela prevedenih u inostranstvu $1944-1958$.

${ }^{70}$ РГАНИ. Ф. 5, Оп. 17. Д. 536. Л. 8, А. Румянцев, Б. Пономарев - в ЦК КПСС, 8. 4. 1955; DA MSP, PA, 1955, f. 62, dos. 3, 416602, Tekući politički izveštaj Ambasade FNRJ u Moskvi, 6. 12. 1955; Isto, f. 65, dos. 6, 48549, Prica - Ambasadi FNRJ, Moskva, 28. 6. 1955; Isto, dos. 7, 48712, Vidić - Sekretarijatu za inostrane poslove, 29. 6. 1955; Isto, dos. 8, 416603, Dragutin Rožman - Državnom sekretarijatu za inostrane poslove, 7. 12. 1955; Isto, Informacija o pozorišnom komadu „Aleko Dundić“.

71 Д. Чосич, Солнцее далеко (Москва: Издательство иностранной литературы, 1956).

72 Исти, „Солнце далеко“, Роман-газета, Но. 4-5/1956.

${ }^{73} \mathrm{AJ}, 498-24$, Zapisnik br. 2 sa sastanka Komisije za plasiranje književnih dela u inostranstvu, 11. 10. 1956.

${ }^{74} \mathrm{AJ}$, fond 559, Savezna komisija za kulturne veze sa inostranstvom, fascikla 17, Zabeleška o razgovoru sa zamenikom ministra kulture Nazarovim, Bogdan Osolnik, 11. 11. 1955. 
„veliki skup čitalaca posvećen Ćosićevom romanu 'Daleko je sunce'“. ${ }^{75}$ Činjenica da je takva usredsređena pažnja poklonjena književnom prvencu D. Ćosića nesumnjivo je - pored književne vrednosti romana - proisticala iz utisaka koje je on ostavio u SSSR-u.

\section{REFERENCE}

- Chosich, D. Solnce daleko. Moskva: Izdatel'stvo inostrannoj literatury, 1956.

- Chosich, D. „Solnce daleko“. Roman-gazeta, no. 4-5, 1956.

- Ćosić, Dobrica. Piščevi zapisi (1951-1968), drugo izdanje. Beograd: Filip Višnjić, 2001.

- Ćosić, Dobrica. Razgovori i životopis. Beograd: Filip Višnjić, 2005.

- Ćosić, Dobrica. Prijatelji, prir. Ana Ćosić-Vukić. Beograd: Politika, 2005.

- Dimić, Ljubodrag. „Jugoslovensko-sovjetski odnosi u 1954. godini (hronologija događaja)“. U: Balkan posle Drugog svetskog rata. Zbornik radova sa naučnog skupa. Odg. ur. Petar Kačavenda, 155-165. Beograd: ISI, 1996.

- Dimić, Ljubodrag. „Jugoslovensko-sovjetski odnosi 1953-1956. Zbliženje, pomirenje, razočarenje“. U: Jugoslovensko-sovjetski sukob 1948. godine. Zbornik radova sa naučnog skupa. Odg. ur. P. Kačavenda, 279-293. Beograd: ISI, 1999.

- Dobrenko, Evgenij Aleksandrovich. „Vostochnoevropejskie literatury na Vtorom s,,ezde pisatelej i proekt literaturnogo Pax Sovietica: nachalo konca“. U: Vtoroj Vsesoyuznyj s,,ezd sovetskih pisatelej. Ideologiya istoricheskogo perekhoda i transformaciya sovetskoj literatury. 1954: kollektivnaya monografiya. Otv. red. V. YU. V'yugin, 134-166. Sankt-Peterburg: Aletejya, 2018.

- Đukić, Slavoljub. Čovek u svom vremenu. Razgovori sa Dobricom Ćosićem. Beograd: Filip Višnjić, 1989.

- Edemskij, Andrej Borisovich. Ot konflikta $k$ normalizacii. Sovetskoyugoslavskie otnosheniya v 1953-1956 godah. Moskva: Nauka, 2008.

- Gatalović, Miomir. Darovana sloboda. Partija i kultura u Srbiji 1952-1958. Beograd: ISI, 2010.

- Jovanović, Miroslav. Srbi i Rusi 12-21. vek (istorija odnosa). Beograd: Narodna biblioteka Srbije, 2012.

- Jugoslovensko-sovjetski odnosi 1945-1956. Zbornik dokumenata. Prir. Ljubodrag Dimić, Miladin Milošević, Đorđe Borozan, I. V. Buharkin, L. V. Vnukova, J. A. Zelenko, M. K. Kravčenko i V. A. Soljanski. Beograd: Ministarstvo spoljnih poslova Republike Srbije, 2010.

- Kravar, Zoran. „Franičević, Marin“, Hrvatski biografski leksikon. 4. E-Gm. Zagreb: Leksikografski zavod Miroslav Krleža, 1998, 372-374.

- Luburić, Radoica, prir. Pomirenje Jugoslavije i SSSR-a 1953-1955. Tematska zbirka dokumenata. Podgorica: Istorijski institut CG, 1999.

\footnotetext{
${ }^{75}$ AJ, 498-41, Б. Полевой - А. Вучо, 12. 5. 1956.
} 
- Marković, Predrag J. Beograd između Istoka i Zapada 1948-1965. Beograd: Službeni list SRJ, 1996.

- Marković, Predrag J. „Tito i njegovo doba“, u: Marković, Predrag J., Vladimir Kecmanović, Tito, pogovor. Beograd: Službeni glasnik, 2012.

- Miloradović, Goran. Lepota pod nadzorom. Sovjetski kulturni uticaji u Jugoslaviji 1945-1955. Beograd: ISI, 2012.

- Nikolić, Kosta. Srpska književnost i politika 1945-1991. Glavni tokovi. Beograd: Zavod za udžbenike, 2012.

- Pelikán, Jan. Jugoslávie a východní blok 1953-1958. Praha: Univerziteta Karlova v Praze, 2001.

- Popović, Radovan. Vreme pisca. Beograd: Službeni glasnik, 2009.

- Radvoljina, Ida Markovna. Dugačko pismo koje nije stiglo do primaoca. Sremski Karlovci-Novi Sad: Izdavačka knjižarnica Zorana Stojanovića, 2011.

- Selinić, Slobodan. Književna diplomatija. Međunarodna saradnja jugoslovenskih pisaca od sredine pedesetih do kraja sedamdesetih godina 20. veka. Beograd: INIS, 2019.

- Vtoroj vsesoyuznyj s"ezd sovetskix pisatelej. 15-26 dekabrya 1954 g. Stenograficheskij otchet. Moskva: Sovetskij pisatel', 1956.

-Vtoroj Vsesoyuznyj s"ezd sovetskix pisatelej. Ideologiya istoricheskogo perexoda i transformaciya sovetskoj literatury. 1954: kollektivnaya monografiya. Otv. red. V. YU. V'yugin. Sankt-Peterburg: Aletejya, 2018.

- Vstrechi i peregovory na vysshem urovne rukovoditelej SSSR $i$ Yugoslavii v 1946-1980 gg. Tom pervyj 1946-1964. glav. red. M. Miloshevich, V. P. Tarasov, N. G. Tomilina. Moskva: Mezhdunarodnyj fond „Demokratiya“, 2014. 
ANDREY BORISOVICH EDEMSKIY, PhD, Senior Research Associate Institute for Slavic Studies, Russian Academy of Sciences

Moscow, Russian Federation

and-edem@yandex.com

MA MOMIR NINKOVIĆ, PhD Candidate

Faculty of Philosophy, University of Belgrade

Belgrade, Republic of Serbia

momirninkovic22@gmail.com

\section{"GOODWILL MISSION"- DOBRICA ĆOSIĆ AT THE SECOND CONGRESS OF SOVIET WRITERS (DECEMBER 15-26, 1954)}

\section{Summary}

The article reveals the events of Yugoslav-Soviet normalization of contacts in the cultural sphere in 1954-1955. It focuses on the participation of Dobrica Ćosić as a member of the delegation of Yugoslav writers in the work of the Second Congress of Soviet writers, held in Moscow in the second half of December 1954, which, as new documents now have revealed, had a decisive effect on the later renewal of cultural ties between the two countries in 19551956. Not focusing so much on the political contexts of these developments, the authors have taken into account the main events in the political sphere, which took place in 1954. The authors consider the participation of Yugoslavs in the activities of the Congress and the speech delivered at the end of the event, as important inputs for the subsequent full restoration of cultural exchange between the two countries. Soviet archival documents reveal how D. Ćosić reacted to the different circumstances in Moscow, where changes of the slackening Stalinist approaches were already under way. The article demonstrates the role that Ćosić's trip played in the general normalization of Soviet-Yugoslav relations and even influenced the formation of the Soviet leadership's decision not to consider the Yugoslav way of socialist construction as an obstacle to normalization. Because the research prior to writing this article was conducted by the simultaneous and equal use of Soviet and Yugoslav documents from the archives in Moscow and Belgrade, a meticulous comparison of these documents of both sides makes it possible to verify the assessments made.

KEYWORDS: Yugoslavia, Soviet Union, 1954, Normalization, Dobrica Ćosić, Marin Franičević, Second Congress of Soviet Writers, Leonid Leonov, Ida Markovna Radvolina 